\title{
RECONSTRUCTING THE OPENING SESSION OF THE LONG PARLIAMENT
}

Proceedings in the Opening Session of the Long Parliament: House of Commons.

Edited by Maija Jansson. Rochester, NY, and Suffolk, UK: University of Rochester Press.

Volume 1: 3 November - 19 December 1640. 2000. Pp. $1 \mathrm{x}+678$. ISBN 1 58046037 2. Price $£ 90.00$.

Volume 2: 21 December 1640 - 20 March 1641. 2000. Pp. $\mathrm{x}+836$. ISBN 1 58046074 7. Price $£ 90.00$.

Volume 3: 22 March-17 April 1641. 2001. Pp. xxxvii + 608. ISBN 158046 089 5. Price $£ 90.00$.

Volume 4: 19 April - 5 June 1641. 2003. Pp. xxii + 744. ISBN 158046112 3. Price $£ 90.00$.

Volume 5: 7 June - 17 July 1641. 2005. Pp. xxviii + 690. ISBN 158046193 X. Price $£ 90.00$.

Volume 6: 19 July - 9 September 1641. 2005. Pp. xiv + 721. ISBN 158046 218 9. Price $£ 90.00$.

Volume 7: Appendixes and Indexes. 2007. Pp. xii + 401. ISBN 158046224 3. Price $£ 70.00$

These seven volumes represent another landmark in the remarkable sequence of editions produced by the Yale Center for Parliamentary History. In the early 1920s, Wallace Notestein founded the project at Yale of editing all the surviving accounts of English parliamentary proceedings between the accession of James I and the outbreak of the Civil War. A series of highly distinguished scholarly editions has appeared, 
and these important volumes mark a further major step towards completion. Only the proceedings of the 1624 Parliament still remain as yet unpublished. Under the expert direction of Maija Jansson, the Center has continued to perform a signal service to scholars of early seventeenth-century England, and the present volumes more than live up to the very high standards set by their predecessors.

The situation for the Long Parliament has hitherto been incomplete and somewhat anomalous. The earliest edition to appear was Wallace Notestein (ed.), The Journal of Sir Simonds D'Ewes from the beginning of the Long Parliament to the Opening of the Trial of the Earl of Strafford (New Haven, 1923). This printed D'Ewes's journal for the period from 3 November 1640 to 22 March 1641, and included in footnotes material drawn from other manuscript diaries. Notestein's criterion was to include 'whatever seemed at all to add or differ' from D'Ewes's account, ${ }^{1}$ but such excerpts were necessarily selective and were detached from their original contexts. Notestein's pupil W.H. Coates followed the same editorial convention of using D'Ewes as the basic text and then adding annotations from other diaries when he edited another portion of D'Ewes's diary, covering the period from 12 October 1641 to 10 January 1642 (Willson Havelock Coates [ed.], The Journal of Sir Simonds D'Ewes from the First Recess of the Long Parliament to the Withdrawal of King Charles from London [New Haven, 1942]).

What the early months of the Long Parliament thus lacked was the kind of edition that set out the proceedings of the Houses, giving the entries from every surviving diary for each day in turn. Over the years, and especially from the 1970s onwards, Yale published a series of such editions for the early Stuart Parliaments, ${ }^{2}$ but 
for a long time nothing comparable existed for the Long Parliament. Between 1982 and 1992, this deficiency was remedied for most of 1642 by the publication of three excellent volumes that print the surviving private diaries from January to September of that year: Willson H. Coates, Anne Steele Young, and Vernon F. Snow (eds.), The Private Journals of the Long Parliament, 3 January to 5 March 1642 (New Haven, 1982); Ibid., 7 March to 1 June 1642 (New Haven, 1987); Ibid., 2 June to 17 September 1642 (New Haven, 1992). These followed the now standard chronological layout, collecting all the extant materials for each day of proceedings. They were also notable for the high quality of their introductory and editorial material.

The present volumes are thus enormously welcome because they print the private diaries for the House of Commons from the assembling of the Long Parliament on 3 November 1640 until the beginning of the first recess on 9 September. These have not before been published in their entirety, although portions of some other diaries have appeared and are not reproduced here. ${ }^{3}$ This now leaves only two gaps in the published materials of this kind for the period from the meeting of the Long Parliament until the outbreak of the English Civil War. First, although these volumes effectively supersede Notestein's 1923 edition of D'Ewes (from 3 November 1640 to 22 March 1641), we still await a diurnal printing of the Commons diaries for the period covered by Coates's 1942 edition of D'Ewes (from 12 October 1641 to 10 January 1642). Second, a printed edition of materials relating to the House of Lords is urgently needed. These are included in the present volumes only where they relate to joint proceedings of both Houses (for example during Strafford's trial in volumes 3 and 4). ${ }^{4}$ It is to be hoped that editing on both these projects can be brought to completion as quickly as possible. 
The daily entries in the present volumes begin with the relevant section of the House of Commons Journal. These extracts are helpfully taken directly from the manuscript Journal in the House of Lords Record Office rather than from the early nineteenth-century printed version, which quite frequently departs from the original manuscript, although usually only in fairly minor ways. Secondly, for most days there is an extract from D'Ewes's journal, taken from British Library, Harleian Manuscripts 162 (7 November 1640 - 3 April 1641), 163 (6 April - 6 August 1641), 164 (6 August - September 1641) and 165 (which includes miscellaneous early material, for example from November and December 1640). D'Ewes's journal covers virtually the whole of the period in question, and for some of the time it is the only such source available to us, for instance on the following days: 29-31 December 1640, 1-2 January, 21, 23, 25-27, 31 August, and 1-2 September $1641 .{ }^{5}$ Then there is John Moore's journal, taken from British Library, Harleian Manuscripts 541 (19 November - 10 December 1640), 476 (23 February - 16 April 1641), 477 (10 May - 4 June 1641), 478 (16 April - 25 June 1641) and 479 (26 June - 16 August 1641). This covers most of the period except for 11 December 1640 to 22 February 1641, inclusive, for which the diary is presumed lost. The fourth source is Framlingham Gawdy’s diary, taken from British Library, Additional Manuscripts 56103 (3-30 November 1640) and 14828 (22 February - 2 July 1641). Two other diaries provide accounts for most of this period: Thomas Peyton's diary (University of Minnesota Library, MS 137 [6 November - 24 December 1640; 4 January - 30 November 1641; and 1 December 1641 - 17 March 1642]); and Sir John Holland's diary (Bodleian Library, MSS Rawlinson C. 956 [6-29 November 1640; 21 January 1642], Rawlinson D. 1099 [22 May - 8 August 1641], and Rawlinson D. 932 [8 November - 18 December 1641]). 
Also included are four manuscript diaries whose coverage is much more patchy: Geoffrey Palmer's journal (Cambridge University Library, MS KKvi 38 [3 November 1640 - 4 January 1641, with further notes from May 1641]); Thomas Wyse's diary (Cornwall Record Office, BO/23/59 [Antony], [9 November - 17 December 1640]); an anonymous diary (British Library, Harleian Manuscript 1601 [1 March - 10 April 1641]); and another anonymous diary (British Library, Harleian Manuscript 5047 [17 May - 30 August 1641]). Three further manuscript sources are included that relate only to all or parts of the proceedings against Strafford: an anonymous diary (British Library, Additional Manuscript 41688 [5-17 April 1641]); Denzil Holles's notes (British Library, Harleian Manuscript 6865 [23 March - 10 April 1641]); and John Lord Robartes's diary (British Library, Harleian Manuscript 2233 [notes on Strafford's trial]).

All in all, this is a remarkably complete and thorough assembling of the surviving materials for the House of Commons during the first session of the Long Parliament. Of all these private diaries, only that of D'Ewes has been edited and published before. The greatest concentration of new material lies in what has often been referred to as 'the gap' between the Notestein and Coates editions (that is, from the beginning of Strafford's trial on 22 March 1641 until the recess on 9 September 1641), to be found here in volumes 3-6. The core of this material is derived from the diaries of D'Ewes, Moore and Holland, the three anonymous diaries, and the various sources relating to Strafford's trial. The quality of the editorial material, and of the indexes and appendixes, is extremely high. The number of errors is notably low for a project of this scale and complexity, and those that did creep in are corrected in a helpful list of errata in the final volume. ${ }^{6}$ I thought it a pity that there are no finger indents for each day, such as in the Yale edition of proceedings in the 1628 
Parliament, although it may well be that the cost of making these would have been prohibitive. Throughout, the footnotes are consistently full and helpful, and they constitute not only a remarkable achievement of scholarly annotation but also an invaluable aid to further research.

The benefits to scholars of this kind of edition are immense. The gathering together of the diurnal entries in the official Commons Journal and the private journals and diaries, together with the detailed and extremely useful Order of Business at the beginning of each day's proceedings, allows for very easy crosschecking between different accounts of the same items of business. It is also most welcome to have various supplementary material included where relevant. For example, large numbers of petitions were submitted to the Commons, especially in the opening weeks of the Long Parliament, complaining about grievances that had arisen during Charles I's Personal Rule. These are referred to in the journals and diaries, and it is very useful to have the full texts included, taken from original manuscripts that are often in the House of Lords Main Papers in the House of Lords Record Office, or in other cases in the National Archives, the British Library or the Bodleian Library. ${ }^{7}$ It is also helpful to have further variant versions of members' speeches, not found in the journals and diaries, where they exist. ${ }^{8}$

Volume 3 contains some particularly valuable supplementary materials relating to the trial of Strafford, including the articles of impeachment against the Earl together with his responses (pp. 8-48), various items drawn from his correspondence in the Wentworth Woodhouse Manuscripts (pp. 181-5, 405-6), and the depositions of witnesses against him (pp. 402-5). The final volume contains not only a full index to all seven volumes, together with an index of legal citations, but also a number of very helpful appendixes. These include a series of reference tables and lists, such as lists 
of members of the Commons by family name and constituency; a list of officials by office and family name; a table of bills; a list of committees of the Commons; a chronological list of messages, conferences, and reports of conferences; a list of petitions to the Commons; and a chronological table of printed and manuscript accounts of separate speeches that were delivered in the Commons between November 1640 and September 1641. Lastly, there are some additional parliamentary materials, including various manuscript notes relating to particular days, several parliamentary letters and instructions, and some items relating to Parliament and Strafford. The inclusion of all these additional materials greatly enhances the value of these volumes to scholars.

\section{II}

Like previous editions of parliamentary diaries, these volumes raise certain methodological problems for historians. Those problems arise in particular from the discrepancies between the different accounts that survive of many members' speeches. One example, chosen more or less at random from very early in the session, will suffice to show the nature of the difficulties. Six accounts survive of Sir John Strangways' speech on 13 November 1640 (volume 1, pp. 131, 132, 134, 135, 138, 141), as follows:

Sir John Strangways desired (example, 1 R. 2) supply to be given for the war and named the treasurers who took their oaths for honest laying out. He said that he heard that one hundred thousand pounds for the present would keep the armies together and do the other business, etc. This he moved in respect of the 
necessity, and that no subsidies should be irregularly granted but in the right order (videlicet, last of all), etc. (Sir Simonds D’Ewes)

Sir John Strangways. That a $£ 100,000$ will serve the turn for the present, but the manner he leaves. (Framlingham Gawdy)

Sir John Strangways. The work in hand to retain the King's army that it may not be disbanded and the English counties retained. He remembered 11 R. 2. The contribution for the seas with a protestation it should not be drawn in consequence for supplies before grievances were retained. A maxim at court to receive injuries and give thanks, but not for the Commons who have borne such pressures. 1 R. 2. A supply with special directions for treasurers and they took their oaths the money should be expended to that use. (Geoffrey Palmer)

Sir John Strangways. That 1 R. 1 [sic], an aid was given, etc., and treasurers appointed to see it effectually expedited. He said for the present necessity he thought $1000,000 £$ would supply the occasions and keep the treaty in state. (Sir Thomas Peyton)

Sir John Strangways. 11 R. 2, a gift was given upon extraordinary occasions in the beginning of parliament. Ed. 3, an aid was given for the waging the wars. It was put into hand so as the monies might be rightly expended. Propounded that the wisdom of the committee would take into consideration such a supply as might keep the army afoot and that he was informed that $100 \mathrm{M} £$ would keep this, each thing, the truce of the treaty. (Sir John Holland) 
[Sir John Strangways.] 11 R. 2. Money given in the beginning of parliament. The Lords said that they were enforced to give that counsel the Commons have given. To be given upon condition, 1 R. 2. That 100,000 li would supply the present. (Thomas Wise)

This is but one instance chosen from very many, and the problem that it illustrates has given rise to a lively and interesting scholarly controversy.

To be sure, it has long been recognised that the diaries cannot be taken as some kind of early equivalent of Hansard and treated as though they were a record of the exact words that a member spoke on a given day. But historians have been divided over what implications this fact has for the use that scholars can make of these sources. In particular, Geoffrey Elton and Jack Hexter, and more recently John Morrill and Maija Jansson, have debated at length how historians should approach the diaries, and whether they pose special evidential problems that are generically distinct from other primary sources. ${ }^{9}$ Given that accounts of the same speech often differ significantly, there is no straightforward way to determine whether one diary is likely to be closer than another to the original words spoken. Members kept diaries in a variety of ways and for a range of different reasons. Some (for example Gawdy) are the notes that they took in the Commons, often sitting in uncomfortably cramped conditions, whereas others (such as D'Ewes) seem to be fair copies written up at some later date. The diaries thus reflect the individual interests and working habits of their authors.

Furthermore, it cannot even be guaranteed that speeches recorded in the private diaries were ever actually delivered. D'Ewes's diary contains many lengthy 
and elaborate speeches that he claimed to have made, but that are not mentioned in any other sources. ${ }^{10}$ It is possible that he was what John Morrill has called 'the Walter Mitty of the Long Parliament', ${ }^{11}$ and that his diary was in part a retrospective fantasy containing what he wished he had said, or would have liked to have said had he had the opportunity to do so. Although D'Ewes is probably an extreme example, it is likely that other diarists also succumbed to the temptation to extend or polish their own speeches.

Equally, the absence of references to a speech in the diaries does not necessarily prove that it was never given. Diarists naturally tended to focus on the most dramatic or memorable moments in Parliament. A further related problem is that speeches published as 'separates' were often embellished and rewritten, and sometimes had never been delivered at all. This became a greater problem after the early 1640s than earlier, when the abolition of existing controls on printing enforced through the Court of Star Chamber led to a proliferation of printed 'separates'. But, as Alan Cromartie has shown, a significant proportion of these items were fabrications. ${ }^{12}$ To take one important example, fifteen of the thirty-three speeches attributed to John Pym between November 1640 and October 1643 were probably fabricated. ${ }^{13}$ It is often extremely difficult to sort out which editions were actually authorised by the members who allegedly delivered them, let alone how closely they resembled the speeches as originally given.

The private diaries are thus more complicated and problematic sources than they might at first appear. Although the difficulties do resemble those inherent in all primary sources,${ }^{14}$ the diverse origins and nature of the diaries, and the fact that they seem to offer an attractively direct contact with the words of the past, produce distinctive problems of their own. ${ }^{15}$ Moreover, when historians quote from the diaries 
they often choose the most vivid or striking version of a passage, even though that is not necessarily the most reliable, and it is on this issue of quotation that academic controversy has focused. Jack Hexter advocated the careful collation of the different recorded versions of speeches and then the application of existing scholarly conventions for quotation from primary sources: he argued that difficulties were best dealt with on an ad hoc basis and should not dissuade us from quoting from the diaries. ${ }^{16}$ More recently, John Morrill has compiled a useful set of guidelines for the reconstruction of what was said in seventeenth-century Parliaments, drawing out the above problems and suggesting ways to guard against them. In particular, he has urged historians not to prefer one account to another unless there are very good reasons for doing so, and, when faced with several different versions, to collate and paraphrase rather than quote directly from a single source which may be misleading. ${ }^{17}$ Against this, Maija Jansson has asserted the need to quote from these diaries, as from other historical sources. She argues that this is especially necessary on those occasions when one particular diary contains the only extant source for proceedings, and she points out that for historians to eschew quoting from these diaries would constitute a self-denying ordinance that does not obtain elsewhere within the historical profession. ${ }^{18}$

It is possible that the positions of Morrill and Jansson are not quite as far apart as their exchange might suggest, and that they agree about far more than they disagree about. For example, they share much common ground with regard to the crucial importance of collating and comparing the different surviving accounts of speeches. The great advantage of this kind of edition is that it makes it vastly easier and more convenient for historians to confront evidential issues like this. Without them, it is not always easy even to become fully aware of the difficulty, or to get a clear sense of 
its nature and dimensions. Ultimately this will remain a problem without a solution because there is no definitive way of establishing the words that a member uttered on a given day. My own view is that there is no reason to avoid quoting from these diaries, provided that one habitually intrudes some word like 'allegedly' or 'reportedly' before doing so, and that one always bears in mind that these are private reports not verbatim transcripts. It also seems important wherever possible to try to choose the most reliable account rather than merely the most quotable, although the varying degrees of reliability among diarists is not always at all easy to establish.

The Morrill/Jansson debate arose particularly in relation to some of the Yale editions of parliamentary proceedings for the 1620s. The specific problem posed by the records of the first session of the Long Parliament is in one way slightly different in that for most days there are simply fewer surviving accounts than for many of the Parliaments of the 1620s. For example, whereas between five and eight versions are not unusual for the Commons in 1628, the number of extant accounts for 1640-1 rarely gets above four or five. This means that there is less of a problem of which version to choose, but equally less scope for comparison between different accounts. Historians are rather more likely to confront the problem of the unique source in 1640-1 than in 1628. Volume 1 of the present edition covers 39 days, and for all but 3 of them there are surviving accounts from D'Ewes and more than one other diarist, in addition to the Commons Journal. However, the number of accounts decreases markedly in volume 2, which covers 75 days. Of these, 27 are recorded by D'Ewes and more than one other diarist, 43 are recorded by D'Ewes and only one other, and for 5 days D'Ewes is our only source other than the Commons Journal. The situation improves somewhat thereafter: of the 24 days covered in volume 3 , all but one are recorded by D'Ewes and more than one other diarist, while in volume 4, 36 of the 42 
days covered are recorded by D'Ewes and more than one other diarist, and just six by D'Ewes and only one other. This trend continues in volume 5, where all of the 36 days covered are recorded by D'Ewes and more than one other diarist. However, in volume 6 , as we move closer towards the recess, the problem of the unique source resurfaces. For nine of the 39 days covered in this volume, D'Ewes is our only source other than the Commons Journal, while for a further eight days we have D'Ewes and just one other diarist. Only 14 of the days in this volume are recorded by D'Ewes and more than one other diarist. Volume 6 also contains an exceptional period when his wife's illness and death apparently caused D'Ewes to be absent from the Commons for eight days between 22 July and 2 August, inclusive. Fortunately, all eight of these days are covered in at least two other diaries. ${ }^{19}$ There is, in short, considerable fluctuation in the number of accounts that survive of the Commons' proceedings during the course of the opening session of the Long Parliament. Nevertheless, without diminishing the extent of the problems that the diaries pose for historians, the sheer size of the present volumes reminds us that those problems are positive ones in the sense that they derive from the large amount of surviving evidence rather than its paucity. It is salutary to remember that not every field of historical study is blessed with such good fortune.

III

In the light of this extensive body of evidence, it is therefore worth asking what impact the publication of these volumes is likely to have on our understanding of proceedings in the Commons during the first ten months of the Long Parliament. What issues will writers of textbooks on this period henceforth have to explore in 
their accounts? What opportunities and challenges do these volumes offer to scholars working on the years 1640-1?

First of all, this edition brings home perhaps more strikingly than ever before the sheer volume of business that the Commons was handling in these months, and especially during the Parliament's opening weeks. The range and diversity of grievances aired and petitions submitted are remarkable. Two separate days' business, taken almost at random from the first month of proceedings, will serve to illustrate this point. First, on Monday 9 November, the Commons considered the following items of business: a series of disputed election returns; reports of speeches by the Lord Keeper and the King; a motion for supply; discussions with the Lords regarding a fast; a petition from Warwickshire freeholders against their Sheriff, George Warner; a petition from Somerset freeholders; reports from the committee of privileges on certain disputed elections; possible measures against recusants; petitions from William Prynne, Alexander Leighton and John Lilburne; an enquiry into the number of papists in and around London; articles or petitions of grievances presented from Lincolnshire, Yorkshire and Kent; and the disabling of projectors and unlawful monopolists. ${ }^{20}$ On a second day a fortnight later, Monday 23 November, the Commons' order of business comprised: lights at Dungeness and Winterton; various petitions from grocers, salters, dyers, leathersellers, merchants for sheep and lamb skins, and gentlemen of Gray's Inn; various monopolies; a patent for trading in calf skins; an enquiry into the High Constable and Earl Marshal's Court; an investigation of the stabbing of Peter Heywood while on Commons' business; an examination of John James for refusing to take the oath of supremacy; thanks to the King for his care of the House; sending for three members of the Finch family as delinquents; measures against recusants in London; further investigation of the number of papists in and 
around London; the state of the King's army; the oppressions and sufferings of ministers; and finally more petitions, from London churchwardens, St Ives (Huntingdonshire), St Gregory's (London), and from John Spencer against one Fisher. ${ }^{21}$ These two lists reveal the immense variety of public and private business that came before the Commons. They also give some indication of the rich resources that these volumes offer not only for political, constitutional, legal and religious historians, but also for scholars of economic, social and cultural history. The concerns of the realm were directly reflected in the Commons' proceedings and these records thus provide an extremely good way of retrieving the problems that exercised Charles I's subjects in 1640-1.

Furthermore, because - with the very brief exception of the Short Parliament from 13 April to 5 May 1640 - this was the first Parliament to meet since March 1629 , these volumes are a wonderful source for reconstructing the developments of the intervening eleven years. The grievances that had accumulated during Charles I's Personal Rule generated numerous petitions that were often investigated in detail, and many relevant auxiliary materials dating from the 1630s are included here. There is, for example, considerable evidence that illuminates such matters as the nature of Laudian innovations in the Church; ${ }^{22}$ the punishment of Puritan 'martyrs' such as Alexander Leighton, William Prynne, Henry Burton, John Bastwick and John Lilburne $;{ }^{23}$ the drainage of the Fens and reactions to it; ${ }^{24}$ and the raising of Ship Money and the impeachment of those judges who upheld it. ${ }^{25}$ On all of these issues, the sources reveal a deep and widespread desire to dislodge the policies and advisers associated with the Personal Rule.

Of all those advisers, none was more hated and feared than Thomas Wentworth, Earl of Strafford. Much of the material in volumes 3 and 4 is devoted to 
the proceedings against him, which began with the opening of his trial on 22 March 1641 and finally concluded with his execution on 12 May. The diary accounts, together with the documentary appendixes and excellent footnotes, make reconstructing the events of the trial easier than ever before. They throw a great deal of light on Strafford's policies in Ireland and his understanding of his role as Lord Deputy. ${ }^{26}$ His responses to the 28 articles of the charge levelled against him reveal the remarkable intelligence and skill with which he defended himself. ${ }^{27}$ The essence of his defence was to insist that the articles should be taken individually: he maintained that he was not guilty of treason because none of his actions by itself constituted treason. ${ }^{28}$ His prosecutors, by contrast, argued that the articles should be taken jointly: they sought to establish the doctrine of cumulative treason, whereby an accumulation of actions could amount to treason even though none of them did so individually. The magnitude of the task that they faced, and the extreme difficulty of sustaining the idea of cumulative treason, eventually led to the decision to abandon the attempted impeachment and to proceed by bill of attainder instead. The daily proceedings also enable us to chart the close connection between members' demands for Strafford's attainder and their promotion of a bill to prevent the forcible dissolution of Parliament without its own consent. Their wish to ensure that the King was rightly advised meant not only removing evil advisers but also safeguarding the survival of the Long Parliament, a concern that became even more urgent following the revelation of what has come to be called the first Army Plot early in May 1641. These volumes allow us to reconstruct the Commons' investigation of that Plot, together with much supporting material such as depositions, and they demonstrate more fully than ever before the extraordinary complexity of what were in effect two major plots intertwined with several minor conspiracies. Furthermore, the testimony 
of Henry Percy in particular indicates very clearly the extent of Charles I's complicity in the conspiracy to rescue Strafford from the Tower of London. ${ }^{29}$

In addition, volumes 4-6 are interesting because they reveal the beginnings of a backlash in parliamentary opinion towards the King during the summer and early autumn of 1641. This was closely connected to the resurfacing of religious questions from late May 1641 onwards. The Commons returned repeatedly to the future of episcopacy, with heated debates on 27 May; 4, 7, 11-12, 15 and 21 June; 9-10, 15-17, 27 and 29-31 July; and 2-3 August. Then, at the end of August and during the first week of September, attention shifted to communion tables, rails, crucifixes, images and candlesticks. On 1 September, the Commons ordered the churchwardens of every parish church and chapel to 'remove the communion table from the east end of the church, chapel or chancel into some other convenient place', and to 'take away the rails and level the chancels as heretofore they were before the late innovations'. The House also ordered 'all crucifixes, scandalous pictures of any one or more persons of the Trinity, and all images of the Virgin Mary' to be 'taken away and abolished', and all 'tapers, candlesticks and basins' to be 'removed from the communion table'. 'All corporal bowing at the name of Jesus or towards the east end of the church, chapel, or chancel, or towards the communion table' was to be 'henceforth forborne', and 'the Lord's day was to be 'duly observed and sanctified'. Vicars and churchwardens, and Vice-Chancellors of universities, were to 'make certificates of the performance of these orders', and justices of the peace and mayors had the duty to report those who disobeyed them. ${ }^{30}$ Sir John Culpepper successfully moved that an addition be made to the order to "provide a remedy against such as did vilify and condemn the common prayer book established by act of parliament..., or else he feared it might be the occasion of many tumults in the Church and state'. ${ }^{31}$ However, on 6 September, after 
a lengthy debate which according to D'Ewes 'proceeded with much vehemence', the House decided not to include such an addition. ${ }^{32}$ Instead, on 8 September they resolved to publish their order as it stood and urged the Lords to join with them; ${ }^{33}$ but the Lords affirmed their desire 'that the divine service be performed as it is appointed by the Acts of Parliament of this realm'. ${ }^{34}$ The Commons responded by pressing ahead alone, and on 9 September, the day the session was adjourned, they made the remarkable statement that 'the last order of the Lords was made with the consent only of eleven Lords ... Wherefore we expect that the commons of this realm do in the meantime quietly attend the reformation intended without any tumultuous disturbance of the worship of God and peace of the kingdom'. ${ }^{35}$ This willingness to act unilaterally was indicative of a growing radicalism among those advocates of 'further reformation' who commanded what was by now only a narrow majority in the Commons.

These debates during the summer and early autumn of 1641 revealed deepening divisions within the House. While other measures, such as the abolition of Star Chamber, of High Commission and of Ship Money, were agreed relatively straightforwardly, the exchanges on the subjects of episcopacy, the Prayer Book and religious 'innovations' were notable for the intensity of their language, and for the remarkable accuracy with which the stance of members on these issues anticipated their subsequent allegiance to Crown or Parliament. ${ }^{36}$ With very few exceptions, those who advocated further reformation of the Church of England, including the abolition of episcopacy and the demolition of 'innovations', later became Parliamentarians, while those who wished to preserve the existing institutional structures and practices of the Church almost invariably sided with the King. Although this general correlation has been convincingly suggested before, ${ }^{37}$ the 
present volumes now make more readily available than hitherto the primary sources that demonstrate it conclusively.

This polarisation of opinion over religious issues took place against a background of diminishing attendances at the House. Whereas on 26 July 1641, there were still 250 members sitting in the Lower House out of the more than 400 who had originally been returned, by 13 August this figure had fallen to $131 .{ }^{38}$ On 30 August, D'Ewes reported that numbers had dropped below forty, which meant that the House was no longer quorate. ${ }^{39}$ Numbers recovered slightly thereafter: they reached 92 on 1 September, and hovered around 131-134 on 6 September, but then fell back to between 90 and only 52 on 8 September. ${ }^{40}$ In the six votes known to have taken place during the first week of September, the House divided by 55 to 37 on 1 September; by 70 to 64,71 to 60 and 70 to 62 on 6 September; and by 49 to 41 and 29 to 23 on 8 September. ${ }^{41}$ These figures reveal that by the time the session was adjourned on 9 September, opinion among such members as remained in the Commons was already split with an evenness that ominously prefigured the division over the Grand Remonstrance the following November.

All in all, these volumes leave us once again greatly indebted to the Yale Center and especially to its Director, Maija Jansson, and they whet the appetite for future editions. It is devoutly to be hoped that the Center will be able to publish materials for the House of Lords in 1640-2 to match those that already exist for the Commons, and that it will then be possible to continue the project for both Houses through the remainder of the 1640s, down to the abolition of the monarchy and the Lords in 1649 . To judge by the present volumes, the harvest that such a complete edition would yield for scholars of this period would be gargantuan. 
${ }^{1}$ Wallace Notestein (ed.), The Journal of Sir Simonds D'Ewes from the beginning of the Long Parliament to the Opening of the Trial of the Earl of Strafford (New Haven, 1923), p. xi.

${ }^{2}$ So far the following have appeared: Maija Jansson (ed.), Proceedings in Parliament, 1614 (Philadelphia, 1988); Maija Jansson and W.B. Bidwell (eds.), Proceedings in Parliament, 1625 (New Haven and London, 1987); Maija Jansson and W.B. Bidwell (eds.), Proceedings in Parliament, 1626 (4 vols., New Haven and London, 1991-6); and M.F. Keeler, M.J. Cole, and W.B. Bidwell (eds.), Proceedings in Parliament, 1628 (6 vols., New Haven, 1977-83). Earlier editions, employing a slightly different format, include: E.R. Foster (ed.), Proceedings in Parliament, 1610 (2 vols., New Haven and London, 1966); Wallace Notestein, F.H. Relf and H. Simpson (eds.), Commons Debates, 1621 (7 vols., New Haven, 1935); and Wallace Notestein and F.H. Relf (eds.), Commons Debates for 1629 (Minneapolis, 1921). ${ }^{3}$ For example Maija Jansson (ed.), Two Diaries of the Long Parliament (Gloucester, 1984), which printed the diary of William Ogden (University College, London, Ogden MS 7, 51) and an anonymous diary at the Beinecke Library at Yale (formerly Yale Uncatalogued MS 226; now GEN MSS VOL 8). This anonymous diary has subsequently been ascribed to Sir Ralph Verney: see Maija Jansson and Michael Mendle, 'Escape from Anonymity: Sir Ralph Verney', Parliamentary History, 5 (1986), pp. 99-100. Two further instances of notes of parliamentary proceedings already published but not reproduced in the present volumes are: A.H.A. Hamilton, Note Book of Sir John Northcote (London, 1877), which covers 24 November 1640 to 21 June 1641; and John Bruce (ed.), Notes of Proceedings in the Long Parliament ... 
by Sir Ralph Verney, Knight (Camden Society, 31, London, 1845), covering

December 1640 to 27 June 1642.

${ }^{4}$ See, for example, volume 3, pp. 76-7, 98-9, 124-5, 174-5, 202-4, 226-7, 262, 299300, 344-6, 392-3, 443-4, 463-4, 475-6, 491-3, 535-6, 562-3, 599-600; volume 4, pp. 197-8, 221-3, 234, 257-8, 284-5, 326-7.

5 Volume 3, p. xxxvi.

${ }^{6}$ Volume 7, pp. 400-1.

${ }^{7}$ For some examples from November and December 1640, see volume 1, pp. 47-50, 87-9, 180-1, 241-2, 283-4, 299-301, 348, 362-3, 384-6, 429-32, 446-53, 571-5, 638$40,672-8$.

${ }^{8}$ To take the month of January 1641 in volume 2 as a sample: additional variant versions of speeches are included for Sir Simonds D'Ewes on 2 January (pp. 93-5), Sir Edward Dering on 13 January (pp. 187-8), Sir Benjamin Rudyerd and Sir John Wray on 21 January (pp. 239-41), and John Pym on 30 January (pp. 324-6).

9 The initial debate can be found in G.R. Elton, Studies in Tudor and Stuart Politics and Government (4 vols., Cambridge 1974-92), 2, pp. 3-18, the latter part of which is a reply to J.H. Hexter, 'Parliament under the Lens' in British Studies Monitor, 3 (1972-3), pp. 4-15. For Elton's views, see also G.R. Elton, The Parliament of England, 1559-1581 (Cambridge, 1986), pp. 10-14. Hexter made a further contribution in 'Quoting the Commons, 1604-1642', in DeLoyd J. Guth and John W. McKenna (eds.), Tudor Rule and Revolution (Cambridge, 1982), pp. 369-91. More recently, John Morrill has addressed these issues in three articles: 'Reconstructing the History of Early Stuart Parliaments', Archives, 21 (1994), pp. 67-72; 'Paying One’s D'Ewes', Parliamentary History, 14 (1995), pp. 179-86; and 'Getting Over D’Ewes', 
Parliamentary History, 15 (1996), pp. 221-30. The third of these papers is a reply to

Maija Jansson, 'Dues Paid', Parliamentary History, 15 (1996), pp. 215-20.

${ }^{10}$ For some examples of this phenomenon, see volume 1, pp. 355, 420, 421-2, 422, 460-1, 566, 567-8, 589, 623; volume 2, pp. 124-5, 126, 135-7, 144, 173, 184, 191-2, 200, 216, 224, 230-1, 237-8, 247, 249-50, 251-2, 278-9, 281-2, 320-1, 332, 334-5, $343,363,367,399-400,480-1,497-500,520-1,562-4,663-5,694-7,725-7,752-4$, 795-6. The Order of Business at the beginning of each day's proceedings helps to identify at a glance those speeches that are recorded in only one diary.

11 Morrill, 'Paying One's D'Ewes', p. 183.

12 A.D.T. Cromartie, 'The Printing of Parliamentary Speeches, November 1640-July 1642', Historical Journal, 33 (1990), pp. 23-44.

13 John Morrill, 'The unweariableness of Mr Pym: influence and eloquence in the Long Parliament', in Susan D. Amussen and Mark A. Kishlansky (eds.), Political Culture and Cultural Politics in Early Modern England: Essays presented to David Underdown (Manchester, 1995), pp. 19-54, especially pp. 36-9.

14 A point made forcefully in Jansson, 'Dues Paid', especially pp. 215-7, 219-20.

15 Cf. Hexter, 'Quoting the Commons', especially pp. 377-9.

16 See especially Hexter, 'Quoting the Commons'.

17 See Morrill, 'Reconstructing the History of Early Stuart Parliaments', pp. 71-2, and Morrill, ‘Paying One's D’Ewes', p. 186.

18 Jansson, 'Dues Paid'.

19 D'Ewes appears to have been absent on 22, 23, 24, 26, 29, 30 and 31 July, and 2 August 1641.

${ }^{20}$ Volume 1, pp. 51-73.

21 Volume 1, pp. 243-62. 
${ }^{22}$ See especially volume 1, pp. 571-5, 640-8; volume 2, pp. 173-4, 399-400, 530-8; volume 6, pp. 632-6, 654-9.

${ }^{23}$ See especially volume 3, pp. 477-9; volume 4, pp. 35-9, 43-4 (for Leighton); volume 1, pp. 448-52, 527-9, 545-7, 604-6; volume 2, pp. 23-4, 79-80; volume 4, pp. 22-5, 28-9 (for Prynne); volume 1, pp. 36-7, 49-50, 55-6, 437-8, 446-8; volume 2, pp. 23-6, 722-5, 729-31; volume 3, pp. 106-8 (for Burton); volume 1, pp. 47-8, 638-40; volume 2, pp. 162-3 (for Bastwick); volume 1, pp. 64, 67, 69-72; volume 4, pp. 188, 191, 195 (for Lilburne).

${ }^{24}$ See especially volume 2, pp. 611-12; volume 4, pp. 243, 247, 253, 357, 361, 390, 393-4, 401, 532.

25 See especially volume 1, pp. 484-8, 490-2, 494-6, 499-500; volume 2, pp. 192-4.

26 See, for example, volume 3, pp. 354-60.

27 These are very helpfully printed in volume 3, pp. 8-48.

${ }^{28}$ See, for example, volume 3, pp. 521-38.

${ }^{29}$ See especially the proceedings for 12, 14 and 16 June, and 22-23 July 1641.

30 Volume 6, pp. 631-2.

31 Volume 6, p. 634.

32 Volume 6, pp. 648, 653-6 (quotation at p. 655).

33 Volume 6, pp. 676, 686, 692.

34 Volume 6, p. 704; Lords Journal, 4, p. 395.

35 Volume 6, p. 705.

36 The proceedings for 11-12 June 1641 provide an excellent case study of these points.

37 Most notably in Conrad Russell, The Causes of the English Civil War (Oxford, 1990), pp. 220-6. 
38 Volume 6, pp. 90, 396.

39 Volume 5, p. xv; volume 6, pp. 614-15.

40 Volume 6, pp. 632, 648, 675, 678.

41 Volume 6, pp. 632, 648, 675, 678. 